\title{
Climate change adaptation networks for small and medium-sized cities
}

\section{Simone Häußler ${ }^{1}$ (D) . Wolfgang Haupt ${ }^{2}$}

Received: 6 May 2021 / Accepted: 22 September 2021 / Published online: 22 October 2021

(C) The Author(s) 2021

\begin{abstract}
Cities are particularly vulnerable to the impacts of climate change. Many larger cities have identified the potential impacts of different climate change adaptation scenarios. However, their smaller and medium-sized counterparts are often not able to address climate risks effectively due to a lack of necessary resources. Since a large number of cities worldwide are indeed small and medium-sized, this lack of preparedness represents a crucial weakness in global response systems. A promising approach to tackling this issue is to establish regional municipal networks. Yet, how might a regional network for small and medium-sized cities be systematically designed and further developed? Focussing on the German federal state of Baden-Wuerttemberg, we have explored this question by applying a participatory action research approach. As part of our research, we established a regional network framework for small and medium-sized cities. The framework supports small and medium-sized cities in identifying key regional actors, while taking local and regional contextual factors into account. Based on our findings, we suggest that other small and medium sized cities follow these steps: develop the knowledge base; build the network; and transfer and consolidate knowledge.
\end{abstract}

Keywords City networks $\cdot$ Climate change adaptation $\cdot$ Key actors $\cdot$ Knowledge transfer $\cdot$ Regional network framework $\cdot$ Participatory action research

Simone Häußler

Simone.Haeussler@hs-aalen.de

Wolfgang Haupt

wolfgang.haupt@leibniz-irs.de

1 Aalen University, Electrical Engineering - Renewable Energies, Anton-Huber-Straße 25, 73430 Aalen, Germany

2 Leibniz-Institute for Research on Society and Space, Flakenstraße 29-31, 15537 Erkner, Germany 


\section{Introduction}

For many regions worldwide, climate change is leading to an increased intensity and frequency of extreme weather events (Dannenberg et al. 2019; Eckstein et al. 2021). The effects of climate change pose major challenges, especially to cities (Bulkeley 2010; Wamsler et al. 2013; Drolet and Sampson 2017; Palermo et al. 2020). Depending on their specific geographical location, cities are particularly vulnerable (Rosenzweig et al. 2010; Carter 2011) to severe heat waves, due to the urban heat island effect (Menberg et al. 2013; Jiricka-Pürrer et al. 2020), droughts (Kiem and Austin 2013; Guerreiro et al. 2018) and floods (Eckersley et al. 2018; Heidenreich et al. 2020; Dillenardt et al. 2021). Municipal climate adaptation therefore aims to provide cities with concepts and strategies to address and prepare for current and future climate risks, so that threats are avoided or reduced, as far as possible (Jolk 2015).

Particularly, small and medium-sized cities (hereinafter SMCs) with fewer than 100,000 inhabitants (BBSR 2020) often have very limited resources to identify local climate risks and build appropriate adaptation capacities (Otto et al. 2021). It is therefore highly important to examine the activities of such cities to identify the extent to which they will be able to address climate change (Giffinger et al. 2007; Bell and Jayne 2009).

Some SMCs involve themselves in municipal climate networks to support their adaptation efforts (Hauge et al. 2019; Papin 2019; Landauer et al. 2019; Goh 2020). Heikkinen et al. define municipal climate networks as [...] organisations that aim to support cooperation between cities to improve their climate change mitigation and adaptation work (2020). Municipal climate networks are formal, self-governed organisations and have formal structures, such as a head office and a staff of employees (Kern and Bulkeley 2009; Busch 2015; Haupt and Coppola 2019). The most visible networks consist of cities from various countries.

Busch (2015) and Haupt and Coppola (2019) refer to these internationally operating networks as transnational municipal (climate-) networks. Well-known examples are for instance United Cities and Local Governments (UCLG), Local Governments for Sustainability (ICLEI), 100 Resilient Cities and C40 (Labaeye and Sauer 2013; Haupt and Coppola 2019). Most of them, particularly the two latter ones, heavily focus on capital cities and large cities (Hunt and Watkiss 2011; Araos et al. 2016; Gordon 2016; Coppola et al. 2020; Haupt et al. 2020).

SMCs, on the other hand, are significantly less involved in international networks (Haupt and Coppola 2019; Kern 2019). They urgently need support as they often have very limited capacities for action or to pioneer and test their own place-based approaches. More precisely, SMCs need regionally and locally tailored solutions (Granberg et al. 2019). This could be facilitated through the development of regional climate adaptation networks (Stiller and Meijerink 2016; Schmid et al. 2016). A regional network of SMCs could help to form a community that requires each member to input fewer resources and benefit from greater synergies with other participating actors when seeking to address common problems. 


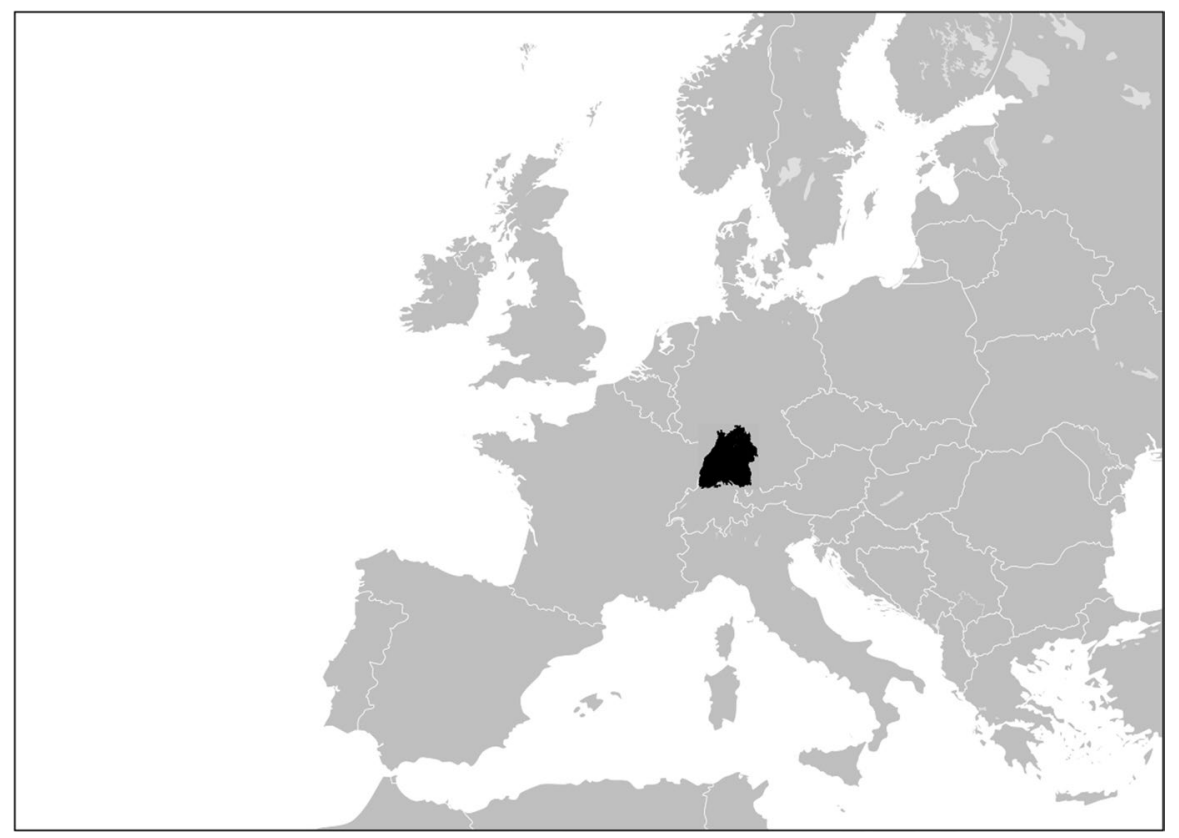

Fig. 1 The location of the German state of Baden-Wuerttemberg on the map of Europe

The aim of our work is to develop a transferable framework for the initiation and establishment of regional networks for climate change adaptation in SMCs. In this respect, we first determine which key actors most effectively support adaptation measures in SMCs (hereinafter question 1). Next, we question how a regional network for SMCs can be systematically designed and established (hereinafter question 2). Our study is based on the hypothesis that regional networks for municipal climate adaptation can effectively promote climate change adaptation practices in SMCs.

Applying a participatory action research (PAR) approach, we established a regional network for municipal climate adaptation in the German state of BadenWuerttemberg in 2020. The network organised and hosted a region-wide workshop. We developed our framework based on manifold interactions with the municipal climate action officers that actively participated in this workshop.

\section{Case selection and case description}

We chose the south-west German federal state (Bundesland) of Baden-Wuerttemberg (Fig. 1) as our focus to demonstrate how municipal climate adaptation practices can be substantially supported by regional networks.

Due to its geographical location on the Upper Rhine Graben, Baden-Wuerttemberg is highly vulnerable to the effects of climate change, such as a steady increase in the number of very hot days and extreme drought (Scholze et al. 2020). The Rhine 
Graben stretches for a total of $300 \mathrm{~km}$ with a width of 30-40 km through Switzerland, France and Germany. It is known for extreme temperature developments along its edges (Harlé et al. 2019). Heat waves have occurred in Baden-Wuerttemberg in the summer months in recent years with high frequency and intensity (Rebetez et al. 2006; Herrmann and Sauerborn 2018). In the years 2003 and 2015, high temperatures and high humidity over long periods of time lead to extreme heat stress, which resulted in a significant increase of the heat-related mortality rate (Muthers et al. 2017).

With a population of approx. 11 million, Baden-Wuerttemberg is the third largest federal state of Germany. Within Europe, its population can be compared to midsize countries like Sweden or Austria. The population of Baden-Wuerttemberg is comparable to that of an American US-state such as Pennsylvania or Ohio. It extends over $35,751 \mathrm{~km}^{2}$ and is characterised by different geographical landscapes, such as the mountainous Black Forest (Feldberg summit $1493 \mathrm{~m}$ a.s.l.) and the Swabian Jura (around $500 \mathrm{~m}$ a.s.1.), with different climate risks (Hackenbruch et al. 2017).

In a comparison of Baden-Wuerttemberg with Germany, Sweden and Austria, it is noticeable that the percentage of inhabitants in large cities is remarkably low. Only one in five inhabitants live in one of the nine large cities of the federal state. Eight of these large cities remain significantly below the 500,000-population mark (Destatis 2020). Only the state capital Stuttgart exceeds this mark with approx. 609,000 inhabitants (ibid.). Stuttgart's particular climate vulnerability is caused by its sink-like basin location (Fallmann et al. 2014; Ketterer and Matzarakis 2014). To address this problem, Stuttgart has developed a climate adaptation strategy (Hebbert and Webb 2012). But above all, the state capital also has more resources and greater capacities for action than any of the other approx. 1100 municipalities in BadenWuerttemberg. Two of the other larger cities within the federal state, Freiburg and Heidelberg, have received numerous awards in recent years for their climate policies and sustainability activities. The city of Freiburg has developed and implemented professional green city branding strategies (Carter 2011; Mössner 2015). Moreover, Heidelberg is one of the few non-megacities to have been accepted into the global pioneer network $C 40$ (Lee and van de Meene 2012). Cities that are pioneering climate policies often have the ambition to attract followers and are referred to as climate policy leaders in academic literature (Liefferink and Wurzel 2018; Wurzel et al. 2019). Heidelberg and Freiburg are such climate policy leaders (Jänicke and Wurzel 2019; Otto et al. 2021). But they are unlikely to find many followers in Baden-Wuerttemberg as their approaches are not easily replicable for SMCs (Haupt 2020). In fact, most SMCs in Baden-Wuerttemberg (as well as in whole Germany) have not yet developed climate adaptation strategies or implemented substantial climate adaptation measures (Otto et al. 2021). This is concerning, because they are home to roughly $80 \%$ of Baden-Wuerttembergs population (Destatis 2020).

Nevertheless, these SMCs will also be increasingly affected by the impacts of climate change. Therefore, there is an urgent need for the development of regionally organised learning networks for SMCs. The scholarly debate (e.g. Matisoff and Edwards 2014; Fisher 2014; Stead and Pojani 2018; Haupt 2020) also suggests that cities with similar size and institutions can more easily learn from each other than cities that are drastically different from one another. 


\section{Materials and methods}

The social psychologist Kurt Lewin is often referred to as the originator of action research (Adelman 1993). Lewin first described his findings from field interviews with workers in his publication Action research and minority problems (1946). While there is no single definition of action research (AR henceforth), there are different approaches to describe this method. Hult and Lennung define it as a method that simultaneously assists in practical problem-solving and expands scientific knowledge (1980). According to Altrichter et al., AR is an enquiry with people, rather than research on people (2002). Van Buuren et al. add that AR essentially is a matter of co-production between practitioners and scientists: scientific knowledge is developed by planning, implementing, evaluating, and refining concrete interventions in concrete practices in close collaboration with these practices $(2015$, p. 9).

AR has evolved over time and there are different variations of the original research design today. In contrast to the AR approach, PAR puts a stronger emphasis on the involvement of practitioners in the knowledge generation process (Cassel and Johnson 2006). Another difference is that PAR often includes well-educated experts and leaders in the research process (ibid.). PAR enables researchers to develop actionable and applied knowledge together with practitioners (Cassel and Johnson 2006).

Previous studies have shown that this methodological approach is well suited for conducting municipal climate adaptation research (e.g. Boezeman et al. 2014; Campos et al. 2016; Ruiz-Mallén 2020; Meriläinen et al. 2021; Vizinho et al. 2021). Inspired by these studies, a PAR network for the federal state of Baden-Wuerttemberg, in Germany, was initiated and established at Aalen University in 2020. The Aalen PAR network is closely tailored to regional SMCs needs, unlike the formally organised municipal networks, which have been discussed in the scientific literature for decades and which show an under-proportional participation rate of SMCs (Haupt and Coppola 2019). As part of this PAR network, a series of workshops, interviews and scientific-practical cooperation was initiated. In this research paper, the methodology and subsequent results of one workshop are discussed.

The overall goal of this joint workshop was to establish a dialogue between scientists and practitioners to find process-oriented solutions to answer the two research questions: which key actors can most effectively support adaptation measures in SMCs? And: how can a regional network for SMCs be systematically designed and established?

All climate action managers registered with Baden-Wuerttemberg's Climate Protection and Energy Agency (KEA) were invited to the workshop as participants. Municipal Climate action managers play an important role for local climate policy in German cities (Wamsler 2015; Kenkmann et al. 2021). They act as crucial interview partners for climate protection research (e.g. Zeigermann et al. 2020) and for climate adaptation research (e.g. Sprondel et al. 2016) because there are still only a few climate adaptation managers in German municipalities. Their tasks are very diverse and vary from municipality to municipality. They range from administrative work and public relations to educational projects and fundraising (Kenkmann et al. 


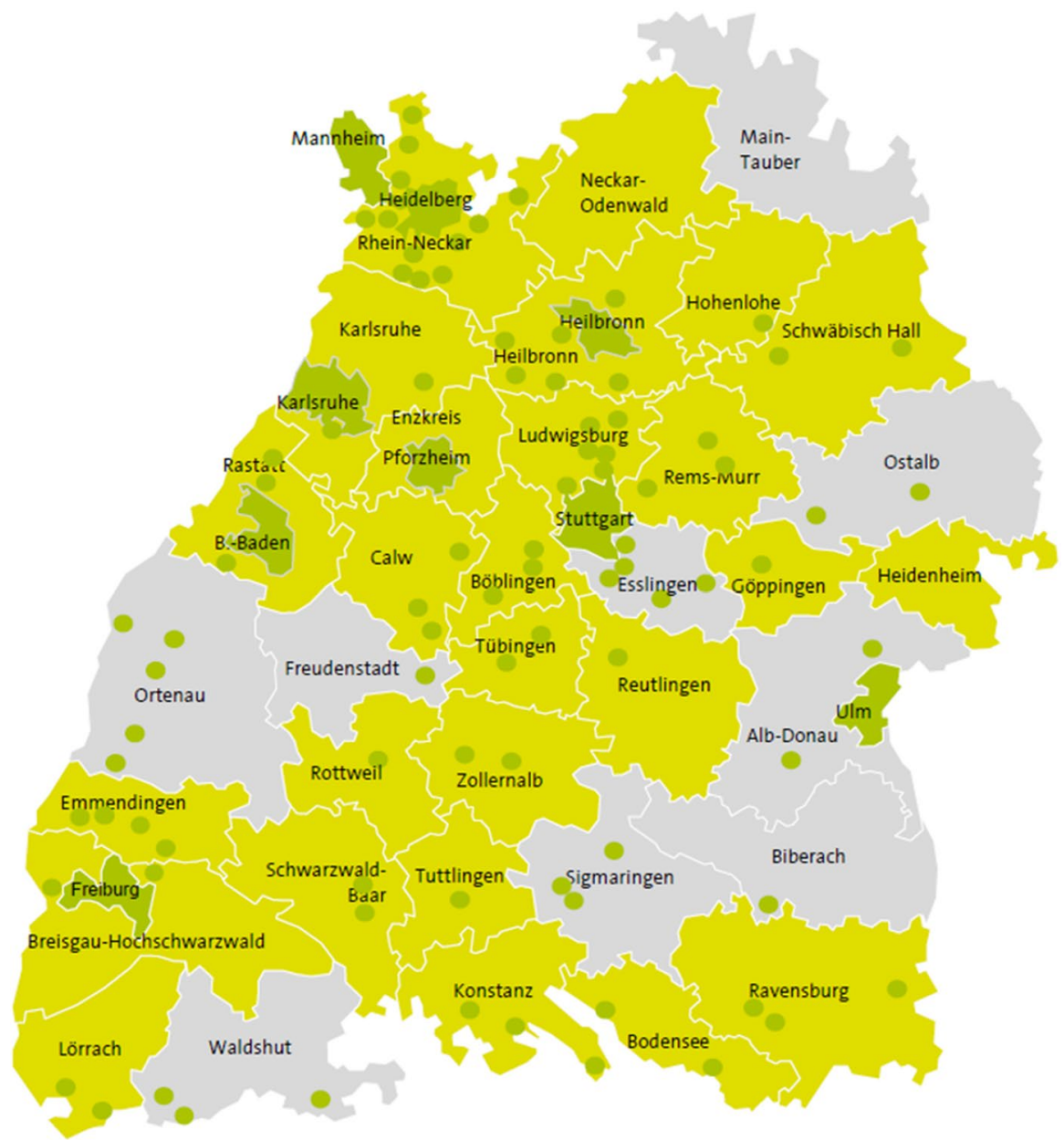

Fig. 2 Map of the German federal state of Baden-Wuertemberg with areas of responsibility, (dark green: municipal responsibility; light green: responsibility at county level; grey: regions without registered municipal climate action managers) extract from KEA (2021)

2021). Across the state, there are about 90 climate action managers registered in the KEA network (KEA 2021). Thirty of them participated in the workshop and are altogether responsible for a total of 105 mainly small and medium-sized cities. Figure 2 illustrates their responsibilities according at the municipal level (dark green) and at the county level (light green). In the grey regions there are no climate protection managers registered with the KEA network.

Due to contact restrictions caused by the Covid-19 pandemic, the workshop took place online on December 12, 2020. The workshop was divided into a theoretical and a practical part. The theoretical part consisted of an introductory lecture and two expert lectures. In the practical part, there were two moderated electronic brainstorming sessions (EBSs, see Maaravi et al. 2020) followed by a discussion. 
In order to include various perspectives and generate a variety of ideas, the participants divided themselves up into three groups (beginners, practitioners and experts in climate adaptation) for each of the two EBSs. With the help of a conference tool ("Zoom"), the participants were given the opportunity to contribute their ideas and record them in writing during the EBSs. The results of the different groups were recorded by four moderators and processed both, deductively-quantitatively (for question 1) and deductively-qualitatively (for question 2). The quantitative results were presented to the participants. This was followed by a discussion and a structured summary of the results. In addition, we compared the results with those of a previous meta-study by Klein et al (2018). The qualitative evaluation was accomplished by applying the step model of inductive category development (see Mayring 2010, p. 84). This was followed by a discussion and further development of the results.

\section{Results}

The first survey was designed to identify potential key actors for municipal climate adaptation. The participants suggested a total of 137 organisations, which have been clustered into three groups: public sector, citizens and private sector. A total of 67 ideas related to the public sector, 23 ideas related to citizens, 15 ideas related to the private sector, and 32 were duplicates or not usable. The public sector cluster included municipal offices (such as the environmental office), educational institutions (such as local universities and colleges), as well as political institutions and the health sector (with hospitals and care institutions). We sub-divided the citizens cluster into citizenship, local clubs and associations, and the private sector included regional companies, regional craftsmanship and farms.

After defining the relevant key actors (who?), we examined the options for action that our participants identified (what is to be done?). In the second survey, the participants identified a total of 106 ideas, which we clustered into knowledge basedevelopment; network-building, and consolidation and knowledge transfer. In a subsequent discussion with all participants, the (individual) results were put into a logical order. This order shows which steps are considered necessary by the participants in order to establish a regional network for SMC. Taken together, these steps form our regional network framework, which is explained step by step below (see also Fig. 3).

\section{First step: development of knowledge base}

First of all, a consistent knowledge base, which all network members can accept and agree upon, is needed. This requires a concise, understandable and practicable presentation of scientific findings for municipalities. Regional Universities, colleges, climate research institutes and other higher education institutions were suggested as 

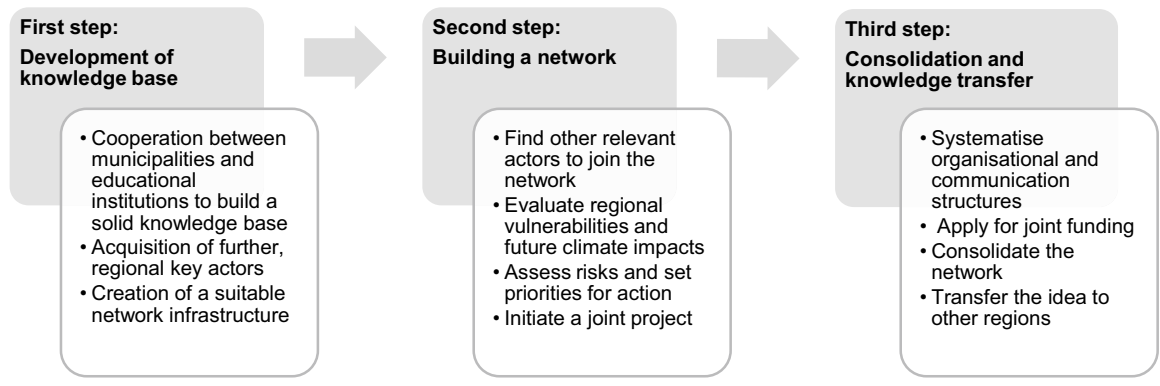

Fig. 3 Steps for building up a regional network framework for SMCs

relevant key actors for developing and providing a common knowledge base. They are able to provide crucial information and support municipalities in setting up their own knowledge management systems, e.g. in creating a suitable online community platform. Complex interrelationships can thereby be presented in a simple and understandable way for stakeholder groups, particularly for citizens. The generated knowledge should be collected on the online platform and provided to the regional network actors. On this basis, measures such as information events, expert lectures and joint newsletters, as well as the conception and implementation of audio-visual climate city tours and geocaching, can be developed.

\section{Second step: network building}

After the identification of regional key actors and the generation and implementation of an accessible knowledge base, the long-term objectives and strategy of the network have to be defined. The process can involve other relevant actors like the private sector including regional companies and local farmers. Classifying and ranking climate risks is a good starting point for climate action in the specific region where the network will be based. In the medium term, joint model projects for climate adaptation should be initiated within the network. This includes, for example, suitable heat plans with well-defined measures in the fields of greening the built urban environment, cloudburst management plans, flood plans for cities near rivers, or mobility strategies.

\section{Third step: consolidation and knowledge transfer}

Finally, the network needs to be consolidated, which is probably the most demanding and time-consuming task. This requires organisational measures. One of these is to establish a head office for the coordination of the regional climate change adaptation network. This office has to establish and maintain effective communication structures that guarantee a continuous exchange of information and promote joint applications for funding in the longer term. Furthermore, the organisational capacity of the key actors in the network needs to be ensured by establishing staff positions 
for the municipal climate action managers within this office. Moreover, cooperation between the network and governmental actors at the state and federal level can also contribute to a better visibility, relevance and communication of the needs of SMCs.

\section{Transferability of the regional network framework}

With regard to the transferability to other regions, policy makers have to consider the following issues:

- SMCs often have little experience in knowledge management and usually lack resources for generating scientific knowledge. Strategic cooperation, e.g. with local universities or colleges, can therefore play an important role (Wamsler et al. 2013; Hackenbruch et al. 2017; Bai et al. 2018). An important factor for the transferability of the framework is cooperating with potential partners that can initiate and establish an effective and adequate knowledge management.

- Even if SMCs have only limited human resources, each participating city should appoint actors responsible for climate action, to take over the role of the coordinator. External individuals can not entirely fill this role because knowledge of internal structures within the municipality is essential. The coordinators must be empowered to implement change processes in the organisation.

- Long-term cooperation between the municipal actors and the stakeholders in the network must be ensured. Short communication and flat hierarchies within the regional network are important for the ability to act proactively.

- The accessibility and quality of the information needs to be adjusted to the target group. To apply the PAR method, the level of abstraction (e.g. in communication) has to be easy to understand, rather practical and focused on action.

- In the long term, the creation of additional positions to ensure the continuity of the network is necessary. This can be achieved by an arrangement in which several municipalities share costs, and in which these new staff are responsible for the maintenance and expansion of the network.

\section{Discussion}

By applying a PAR approach, we have developed a transferable framework for the initiation and establishment of regional networks for climate change adaptation in SMCs. Future research can address the insights and questions raised by a critical look at our results and the academic literature.

Our findings related to question 1 (which key actors can most effectively support adaptation measures in SMCs?) concur with previous research findings (e.g. Klein et al. 2018), as they share the categorisation of different stakeholders into public sector, private sector and citizens. In their meta study of adaptation initiatives, Klein et al. saw the greatest potential in the public sector, followed by citizens` initiatives. However, the climate action managers interviewed in our study saw greater potential in citizens than in the private sector. An explanation might be that the municipal 
climate action managers who participated in our workshop generally have more and stronger interactions with citizens' groups in their daily work than they do with businesses.

With regard to stakeholders for municipal climate adaptation in Baden-Wuerttemberg, Hackenbruch et al. (2017) recommend stronger cooperation between municipalities and climate researchers. At the same time, Hackenbruch et al. note that free scientific climate information services (e.g. online on the website of the Federal Environmental Agency (UBA), or federal state level (LUBW)) are used rarely by municipalities. This suggests that direct cooperation with municipalities, like e.g. within the Aalen PAR network, are a feasible way to exchange information. However, we cannot assume that this applies to all municipalities, because networking is time-consuming and only a fraction of the municipalities in Baden-Württemberg participated in the workshop. Furthermore, PAR approaches outside of BadenWuerttemberg might also lead to (more or less) different results. Whether the results are fully applicable to other regions or even to other German federal states might be questioned. Indeed, German states are relatively autonomous in supporting (or not supporting) their municipalities to prepare for climate change. In order to formulate robust statements about the transferability potential of our framework we need more regional case studies applying a PAR approach.

The previous points dealt mainly with network partners and network building. In addition to these plans, however, it is also important to be aware of the considerations that become important after a loss event. Several scholars emphasise the potential of social ties among residents across locations for preparedness and reconstruction after environmental threats (Rockenbauch and Sakdapolrak 2017; Patterson et al. 2019; Wilkin et al. 2019). Cope et al. (2018) show that in the US American state of Louisiana, which was hit by disasters quite frequently, residents with strong ties to individuals two or more hours away from their community perceive themselves to be better prepared and adequately resourced to cope with environmental threats than individuals with strong ties in their immediate local community.

Our work considered the cooperation of actors within the federal state of BadenWuerttemberg. As described in the case selection, Baden-Wuerttemberg has different geographical landscapes with different climate risks, such as increasingly hot and dry summers (Muthers et al. 2017), hail- and thunderstorms (Puskeiler et al. 2016) or floods (Hennegriff et al. 2006). However, due to its size and variety of landscape, it is unlikely that a single extreme weather event such as a flood or storm will affect the entire state. Moreover, not all municipalities are equally affected by all climate change risks. Thus, for their further development and growth, networks for SMCs should not necessarily stop at regional or national borders and rather be conceptualised and planned on a supra-regional basis, taking into account climate risks and existing institutional and administrative settings. It is therefore conceivable to extend our network to neighbouring states such as Bavaria and the neighbouring countries such as Switzerland and Austria. There is high potential in this expansion, because, geographically speaking, the climate impact will be similar. Moreover, a regional network can be sub-divided into different working-groups focussing on certain climate risks. 


\section{Conclusion}

Climate networks of predominantly large cities have existed since the 1990s (Labaeye and Sauer 2013). In contrast, regional networks for SMCs are far less numerous and visible. Nevertheless, in many regions worldwide large parts of the population live in SMCs (Giffinger et al. 2007; Bell and Jayne 2009). Through its methodical application of a PAR approach this research seeks to provide SMCs with a regional network framework, i.e. an easily transferable and manageable tool for building regional networks. To achieve this, we found practical ideas and solutions in close cooperation with the climate protection managers of the state. Our study demonstrates how to identify key actors who can support municipal adaptation practice. For the case of Baden-Wuerttemberg, the most important actors were in public sector organisations, followed by citizens and the private sector. Strategic cooperation with educational institutions such as universities and colleges plays an important role within the public sector. Based on these findings, we demonstrated how a network for SMCs can be built up systematically. The framework developed in the course of this work consists of three steps: developing the knowledge base; building the network; and consolidating and transferring knowledge to further cases. It fills the gap of regionally and locally tailored solutions for SMCs (Granberg et al. 2019) and contributes to climate adaptation research for SMCs in general. Nevertheless, much more research on how SMCs can successfully tackle local climate adaption challenges is urgently needed. Indeed, SMCs are already affected by the consequences of climate change, and will be affected even more in the future (Drolet and Sampson 2017; Dannenberg et al. 2019). Moreover, they lack the capacity (financial resources and staff) to pioneer climate adaptation policies and do not receive the same (scientific) attention as larger and more-internationally oriented cities (Kern 2019). Given these disadvantages, SMCs need to pool their resources. By joining forces through regional networks SMCs can have the opportunity to exchange crucial information on municipal climate adaptation practice and learn with and from each other.

Funding Open Access funding enabled and organized by Projekt DEAL.

Data availability Not applicable.

\section{Declarations}

Conflict of interest The authors have no relevant financial or non-financial interest to disclose.

Open Access This article is licensed under a Creative Commons Attribution 4.0 International License, which permits use, sharing, adaptation, distribution and reproduction in any medium or format, as long as you give appropriate credit to the original author(s) and the source, provide a link to the Creative Commons licence, and indicate if changes were made. The images or other third party material in this article are included in the article's Creative Commons licence, unless indicated otherwise in a credit line to the material. If material is not included in the article's Creative Commons licence and your intended use is not permitted by statutory regulation or exceeds the permitted use, you will need to obtain permission directly from the copyright holder. To view a copy of this licence, visit http://creativecommons.org/licen ses/by/4.0/. 


\section{References}

Adelman C (1993) Kurt lewin and the origins of action research. Educ Action Res 1(1):7-24. https://doi. org/10.1080/0965079930010102

Araos M, Berrang-Ford L, Ford JD, Austin SE, Biesbroek R, Lesnikowski A (2016) Climate change adaptation planning in large cities: a systematic global assessment. Environ Sci Policy 66:375-382. https://doi.org/10.1016/j.envsci.2016.06.009

Altrichter H, Kemmis S, McTaggart R, Zuber-Skerritt O (2002) The concept of action research. Learn Organ 9(3):125-131. https://doi.org/10.1108/09696470210428840

Bai X, Dawson RJ, Ürge-Vorsatz D, Delgado GC, Barau AS, Dhakal S (2018) Schultz S (2018) Six research priorities for cities and climate change. Nature 555:23-25. https://doi.org/10.1038/ d41586-018-02409-z

BBSR (2020) Laufende Stadtbeobachtung - Raumabgrenzungen. Stadt- und Gemeindetypen in Deutschland. Bundesinstitut für Bau-, Stadt-, und Raumforschung. https://www.bbsr.bund.de/ BBSR/DE/forschung/raumbeobachtung/Raumabgrenzungen/deutschland/gemeinden/StadtGemei ndetyp/StadtGemeindetyp.html. Accessed 30 Aug 2021

Bell D, Jayne M (2009) Small cities? Towards a research agenda. Int J Urban Reg Res 33(3):683-699. https://doi.org/10.1111/j.1468-2427.2009.00886.x

Boezeman D, Vink M, Leroy P, Halffman W (2014) Participation under a spell of instrumentalization? Reflections on action research in an entrenched climate adaptation policy process. Crit Policy Stud 8(4):407-426. https://doi.org/10.1080/19460171.2014.950304

Bulkeley H (2010) Cities and the governing of climate change. Annu Rev Environ Resour. https://doi.org/ 10.1146/annurev-environ-072809-101747

Busch H (2015) Linked for action? An analysis of transnational municipal climate networks in Germany. Int J Urban Sustain Dev 7(2):213-231. https://doi.org/10.1080/19463138.2015.1057144

Campos IS, Alves FM, Dinis J, Truninger M, Vizinho A, Penha-Lopes G (2016) Climate adaptation, transitions, and socially innovative action-research approaches. Ecol Soc 21(1):13. https://doi.org/ $10.5751 /$ ES-08059-210113

Carter JG (2011) Climate change adaptation in European cities. Curr Opin Environ Sustain 3(3):193-198. https://doi.org/10.1016/j.cosust.2010.12.015

Cassell C, Johnson P (2006) Action research: explaining the diversity. Human Relat 59(6):783-814. https://doi.org/10.1177/0018726706067080

Cope MR, Lee MR, Slack T, Blanchard TC, Carney J, Lipschitz F, Gikas L (2018) Geographically distant social networks elevate perceived preparedness for coastal environmental threats. Popul Environ 39(3):277-296. https://doi.org/10.1007/s11111-017-0292-0

Coppola A, Crivello S, Haupt W (2020) Urban IVerning: The Implementation of the 100 resilient cities initiative in Rome and Milan. In: Balducci A, Chiffi D, Curci F (eds) Risk and resilience. springerbriefs in applied sciences and technology. Springer, Cham. https://doi.org/10.1007/ 978-3-030-56067-6_8

Dannenberg AL, Frumkin H, Hess JJ et al (2019) Managed retreat as a strategy for climate change adaptation in small communities: public health implications. Clim Change 153:1-14. https://doi.org/10. 1007/s10584-019-02382-0

Destatis (2020) Städte nach Bundesländern und Einwohnergrößen am 31.12.2019. https://www.desta tis.de/DE/Themen/Laender-Regionen/Regionales/Gemeindeverzeichnis/Administrativ/06-staedteeinwohner-groessen.html. Accessed 03 Sep 2021

Dillenardt L, Hudson P, Thieken AH (2021) Urban pluvial flood adaptation: results of a household survey across four German municipalities. J Flood Risk Manag. https://doi.org/10.1111/jfr3.12748

Drolet JL, Sampson T (2017) Addressing climate change from a social development approach: small cities and rural communities' adaptation and response to climate change in British Columbia, Canada. Int Social Work 60(1):61-73. https://doi.org/10.1177/0020872814539984

Fallmann J, Emeis S, Suppan P (2014) Mitigation of urban heat stress - a modelling case study for the area of Stuttgart. DIE ERDE J Geogr Soc Berlin. 144(3-4), 202-216. https://doi.org/10.12854/erde144-15. https://doi.org/10.12854/erde-144-15

Eckersley P, England K, Ferry L (2018) Sustainable development in cities: collaborating to improve urban climate resilience and develop the business case for adaptation. Public Money Manag 38(5):335-344. https://doi.org/10.1080/09540962.2018.1477642 
Eckstein D, Künzel V, Schäfer L (2021) Briefing paper global climate risk index - who suffers most from extreme weather events? Weather-related loss events in 2019 and 2000-2019. Germanwatch. https:// germanwatch.org/sites/default/files/Global\%20Climate\%20Risk\%20Index\%202021_1.pdf. Accessed 30 Aug 2021

Fisher S (2014) Exploring nascent climate policies in Indian cities: a role for policy mobilities? Int J Urban Sustain Dev 6(2):154-173. https://doi.org/10.1080/19463138.2014.892006

Giffinger R, Fertner C, Kramar H, Meijers E (2007) City-ranking of European medium-sized cities. Cent. Reg. Sci. Vienna UT, 1-12. http://www.smartcity-ranking.eu/download/city_ranking_final.pdf. Accessed 03 Sep 2021

Goh K (2020) Flows in formation: the global-urban networks of climate change adaptation. Urban Stud 57(11):2222-2240. https://doi.org/10.1177/0042098018807306

Gordon DJ (2016) The politics of accountability in networked urban climate governance. Global Environ Polit 16(2):82-100. https://doi.org/10.1162/GLEP_a_00357

Granberg M, Bosomworth K, Moloney S, Kristianssen AC, Fünfgeld H (2019) Can regional-scale governance and planning support transformative adaptation? A Study of Two Places. Sustainability 11(24):6978. https://doi.org/10.3390/su11246978

Guerreiro SB, Dawson RJ, Kilsby C, Lewis E, Ford A (2018) Future heat-waves, droughts and floods in 571 European cities. Environ Res Lett 13(3):034009. https://doi.org/10.1088/1748-9326/aaaad3

Hackenbruch J, Kunz-Plapp T, Müller S, Schipper JW (2017) Tailoring climate parameters to information needs for local adaptation to climate change. Climate 5(2):25. https://doi.org/10.3390/cli5020025

Harlé P, Kushnir ARL, Aichholzer C et al (2019) Heat flow density estimates in the Upper Rhine Graben using laboratory measurements of thermal conductivity on sedimentary rocks. Geotherm Energy 7:38. https://doi.org/10.1186/s40517-019-0154-3

Hauge ÅL, Hanssen GS, Flyen C (2019) Multilevel networks for climate change adaptation-what works? Int J Clim Change Strateg Manag. https://doi.org/10.1108/IJCCSM-10-2017-0194

Haupt W, Coppola A (2019) Climate governance in transnational municipal networks: advancing a potential agenda for analysis and typology. Int J Urban Sustain Dev 11(2):123-140. https://doi.org/10. 1080/19463138.2019.1583235

Haupt W, Chelleri L, van Herk S, Zevenbergen C (2020) City-to-city learning within climate city networks: definition, significance, and challenges from a global perspective. Int J Urban Sustain Dev 12(2):143-159. https://doi.org/10.1080/19463138.2019.1691007

Haupt W (2020) How do local policy makers learn about climate change adaptation policies? Examining study visits as an instrument of policy learning in the European Union. Urban Affairs Rev. https:// doi.org/10.1177/1078087420938443

Hebbert M, Webb B (2012) Towards a liveable urban climate: lessons from Stuttgart. In: Chris Gossop, Shi Nan (eds). Liveable cities: urbanising world: ISOCARP Review 07. London: Routledge, p $132-150$

Heidenreich A, Masson T, Bamberg S (2020) Let's talk about flood risk-Evaluating a series of workshops on private flood protection. Int J Disaster Risk Reduct 50:101880. https://doi.org/10.1016/j. ijdrr.2020.101880

Heikkinen M, Karimo A, Klein J, Juhola S, Ylä-Anttila T (2020) Transnational municipal networks and climate change adaptation: a study of 377 cities. J Clean Prod 257:120474. https://doi.org/10.1016/j. jclepro.2020.120474

Hennegriff W, Kolokotronis V, Weber H, Bartels H (2006) Climate change and floods-findings and adaptation strategies for flood protection. KA-Abwasser, Abfall, 53(8). http://citeseerx.ist.psu.edu/viewd oc/download?doi=10.1.1.529.8978\&rep=rep1\&type=pdf

Herrmann A, Sauerborn R (2018) General practitioners' perceptions of heat health impacts on the elderly in the face of climate change-A qualitative study in Baden-Württemberg, Germany. Int J Environ Res Public Health 15:843. https://doi.org/10.3390/ijerph15050843

Hult M, Lennung SÅ (1980) Towards a definition of action research: a note and bibliography. J Manage Stud 17(2):241-250. https://doi.org/10.1111/j.1467-6486.1980.tb00087.x

Hunt A, Watkiss P (2011) Climate change impacts and adaptation in cities: a review of the literature. Clim Change 104(1):13-49. https://doi.org/10.1007/s10584-010-9975-6

Jänicke M, Wurzel RK (2019) Leadership and lesson-drawing in the European Union's multilevel climate governance system. Environ Polit 28(1):22-42. https://doi.org/10.1080/09644016.2019.1522019

Jiricka-Pürrer A, Brandenburg C, Pröbstl-Haider U (2020) City tourism pre-and post-covid-19 pandemic-messages to take home for climate change adaptation and mitigation? J Outdoor Recreat Tour 31:100329. https://doi.org/10.1016/j.jort.2020.100329 
Jolk A (2015) Klimaschutz \& Klimaanpassung. Wie begegnen Kommunen dem Klimawandel? Deutsches Institut für Urbanistik (Difu). https://difu.de/publikationen/2015/klimaschutz-klimaanpassung. Accessed 30 Aug 2021

KEA (2021) Klimaschutzmanager. https://www.kea-bw.de/kommunaler-klimaschutz/netzwerk/klima schutzmanager. Klimaschutz- und Energieagentur Baden-Württemberg KEA BW. Accessed 03 Sep 2021

Kenkmann T, Eisenmann L, Muckenfuß L (2021) Municipal climate action managers: evaluating the impact. Öko-Institut - Institute for Applied Ecology. https://www.oeko.de/fileadmin/oekodoc/Munic ipal-climate-action-managers.pdf

Kern K, Bulkeley H (2009) Cities, europeanization and multi-level governance: governing climate change through transnational municipal networks. J Common Market Stud 47(1):325-342. https://doi.org/ $10.1111 / \mathrm{j} .1468-5965.2009 .00806 . x$

Kern K (2019) Cities as leaders in EU multilevel climate governance: embedded upscaling of local experiments in Europe. https://www.tandfonline.com/doi/full/https://doi.org/10.1080/09644016.2019. 1521979. Accessed 07 Sep 2021

Ketterer C, Matzarakis A (2014) Human-biometeorological assessment of the urban heat island in a city with complex topography - The case of Stuttgart, Germany. Urban Clim 10:573-584. https://doi. org/10.1016/j.uclim.2014.01.003

Kiem AS, Austin EK (2013) Drought and the future of rural communities: opportunities and challenges for climate change adaptation in regional Victoria, Australia. Global Environ Change 23(5):13071316. https://doi.org/10.1016/j.gloenvcha.2013.06.003

Klein J, Araos M, Karimo A, Heikkinen M, Ylä-Anttila T, Juhola S (2018) The role of the private sector and citizens in urban climate change adaptation: evidence from a global assessment of large cities. Glob Environ Change 53:127-136. https://doi.org/10.1016/j.gloenvcha.2018.09.012

Landauer M, Juhola S, Klein J (2019) The role of scale in integrating climate change adaptation and mitigation in cities. J Environ Plann Manage 62(5):741-765. https://doi.org/10.1080/09640568.2018. 1430022

Labaeye A, Sauer T (2013) City networks and the socio-ecological transition. A European inventory. WWWforEurope Working Paper, No. 27, WWWforEurope, Vienna. http://hdl.handle.net/10419/ 125683. Accessed 07 Sep 2021

Lee T, van de Meene S (2012) Who teaches and who learns? Policy learning through the C40 cities climate network. Policy Sci 45:199-220. https://doi.org/10.1007/s11077-012-9159-5

Lewin K (1946) Action research and minority problems. J Soc Issues 2(4):34-46. https://doi.org/10. 1111/j.1540-4560.1946.tb02295.x

Liefferink D, Wurzel R (2018) Leadership and Pioneership. Exploring their role in polycentric governance. In: Jordan A, Huitema D, van Asselt H, Foster J (eds) Governing climate change: polycentricity in action? Cambridge University Press, Cambridge, pp 135-151

Meriläinen E, Kelman I, Peters LE, Shannon G (2021) Puppeteering as a metaphor for unpacking power in participatory action research on climate change and health. Clim Dev. https://doi.org/10.1080/ 17565529.2021.1930509

Muthers S, Laschewski G, Matzarakis A (2017) The summers 2003 and 2015 in South-West Germany: heat waves and heat-related mortality in the context of climate change. Atmosphere 8(11):224. https://doi.org/10.3390/atmos8110224

Maaravi Y, Heller B, Shoham Y et al (2020) Ideation in the digital age: literature review and integrative model for electronic brainstorming. Rev Manag Sci. https://doi.org/10.1007/s11846-020-00400-5

Matisoff DC, Edwards J (2014) Kindred spirits or intergovernmental competition? The innovation and diffusion of energy policies in the American states (1990-2008). Environ Polit 23(5):795-817. https://doi.org/10.1080/09644016.2014.923639

Mayring P (2010) Qualitative Inhaltsanalyse - Grundlagen und Techniken. 11., aktualisierte und überarbeitete Auflage. Beltz Verlag. Weinheim, Basel

Menberg K, Bayer P, Zosseder K, Rumohr S, Blum P (2013) Subsurface urban heat islands in German cities. Sci Total Environ 442:123-133. https://doi.org/10.1016/j.scitotenv.2012.10.043

Mössner S (2015) Urban development in Freiburg, Germany - sustainable and neoliberal. Die Erde J Geogr Soc Berlin 146(2-3):189-193. https://doi.org/10.12854/erde-146-16

Otto A, Kern K, Haupt W et al (2021) Ranking local climate policy: assessing the mitigation and adaptation activities of 104 German cities. Clim Change 167:5. https://doi.org/10.1007/ s10584-021-03142-9

\section{SN Social Sciences}


Palermo V, Bertoldi P, Apostolou M, Kona A, Rivas S (2020) Assessment of climate change mitigation policies in 315 cities in the Covenant of Mayors initiative. Sustain Cities Soc 60:102258. https://doi. org/10.1016/j.scs.2020.102258

Papin M (2019) Transnational municipal networks: harbingers of innovation for global adaptation governance. Int Environ Agreem 19:467-483. https://doi.org/10.1007/s10784-019-09446-7

Patterson O, Weil F, Patel K (2019) The role of community in disaster response: conceptual models. Popul Res Policy Rev 29:127-141. https://doi.org/10.1007/s11113-009-9133-X

Puskeiler M, Kunz M, Schmidberger M (2016) Hail statistics for Germany derived from single-polarization radar data. Atmos Res 178:459-470. https://doi.org/10.1016/j.atmosres.2016.04.014

Rebetez M, Mayer H, Dupont O, Schindler D, Gartner K, Kropp JP, Menzel A (2006) Heat and drought 2003 in Europe: a climate synthesis. Ann Forest Sci 63(6):569-577. https://doi.org/10.1051/forest: 2006043

Rockenbauch T, Sakdapolrak P (2017) Social networks and the resilience of rural communities in the global south: a critical review and conceptual reflections. Ecol Soc 22(1), 2017. JSTOR, www.jstor. org/stable/26270110.

Rosenzweig C, Solecki W, Hammer S et al (2010) Cities lead the way in climate-change action. Nature 467:909-911. https://doi.org/10.1038/467909a

Ruiz-Mallén I (2020) Co-production and resilient cities to climate change. In: Nared J, Bole D (eds) Participatory research and planning in practice. Springer, Cham, pp 1-11

Schmid JC, Knierim A, Knuth U (2016) Policy-induced innovations networks on climate change adaptation-An ex-post analysis of collaboration success and its influencing factors. Environ Sci Policy 56:67-79. https://doi.org/10.1016/j.envsci.2015.11.003

Scholze N, Riach N, Glaser R (2020) Assessing climate change in the trinational upper rhine region: how can we operationalize vulnerability using an indicator-based, meso-scale approach? Sustainability 12(16):6323. https://doi.org/10.3390/su12166323

Stead D, Pojani D (2018) Dutch experiences of policy mobility in urban planning. In: Dotti NF (eds). Knowledge, policymaking and learning for European cities and regions. From research to practice. Elgar, pp 123-134. https://doi.org/10.4337/9781786433640.00020

Stiller S, Meijerink S (2016) Leadership within regional climate change adaptation networks: the case of climate adaptation officers in Northern Hesse, Germany. Region Environ Change 16(6):1543-1555. https://doi.org/10.1007/s10113-015-0886-y

Sprondel N, Donner J, Mahlkow N, Köppel J (2016) Urban climate and heat stress: how likely is the implementation of adaptation measures in mid-latitude cities? The case of façade greening analyzed with Bayesian networks. One Ecosystem 1: e9280. https://doi.org/10.14279/depositonce-8113

Van Buuren A, Eshuis J, Van Vliet M (2015) Action research for climate change adaptation: Developing and applying knowledge for governance. Routledge, London and New York

Vizinho A, Cabral M I, Nogueira C, Pires I, Bilotta P (2021) Rural renaissance, multifunctional landscapes, and climate adaptation: trilogy proposal from grassroots innovation and participatory action research projects. In: Leal Filho W, Luetz J, Ayal D (eds) Handbook of climate change management. Springer Nature Switzerland. https://doi.org/10.1007/978-3-030-22759-3_55-1

Wamsler C, Brink E, Rivera C (2013) Planning for climate change in urban areas: from theory to practice. J Clean Prod 50:68-81. https://doi.org/10.1016/j.jclepro.2012.12.008

Wamsler C (2015) Mainstreaming ecosystem-based adaptation: transformation toward sustainability in urban governance and planning. Ecol Soc 20(2):30. https://doi.org/10.5751/ES-07489-200230

Wilkin J, Biggs E, Tatem AJ (2019) Measurement of social networks for innovation within community disaster resilience. Sustainability 11(7):1943. https://doi.org/10.3390/su11071943

Wurzel R, Liefferink D, Torney D (2019) Pioneers, leaders and followers in multilevel and polycentric climate governance. Environ Polit. https://doi.org/10.1080/09644016.2019.1522033

Zeigermann U, Kammerer M, Böcher M (2020) Coordinating climate change mitigation policies in rural Germany: a comparative policy network analysis of 32 districts in two Laender. ECPR General Online Conference, 24-28 August 2020, Online. https://www.researchgate.net/publication/34515 9933_Coordinating_climate_change_mitigation_policies_in_rural_Germany_A_comparative_ policy_network_analysis_of_32_districts_in_two_Laender\#fullTextFileContent. Accessed 30 Aug 2021

Publisher's Note Springer Nature remains neutral with regard to jurisdictional claims in published maps and institutional affiliations. 